\title{
Biradical vs singlet oxygen photogeneration in suprofen-cholesterol systems
}

\author{
Fabrizio Palumbo ${ }^{1}$, Francisco Bosca ${ }^{1}$, Isabel M. Morera ${ }^{1}$, Inmaculada Andreu*2 \\ and Miguel A. Miranda*1
}

\section{Full Research Paper}

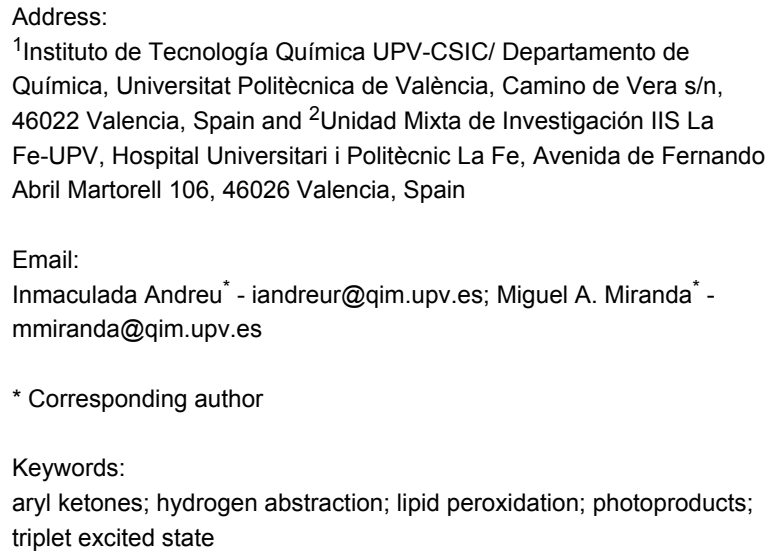

\author{
Beilstein J. Org. Chem. 2016, 12, 1196-1202. \\ doi:10.3762/bjoc. 12.115 \\ Received: 08 March 2016 \\ Accepted: 24 May 2016 \\ Published: 14 June 2016 \\ Associate Editor: J. A. Murphy \\ (c) 2016 Palumbo et al.; licensee Beilstein-Institut. \\ License and terms: see end of document.
}

\begin{abstract}
Cholesterol $(\mathrm{Ch})$ is an important lipidic building block and a target for oxidative degradation, which can be induced via free radicals or singlet oxygen $\left({ }^{1} \mathrm{O}_{2}\right)$. Suprofen $(\mathrm{SP})$ is a nonsteroidal anti-inflammatory drug that contains the 2-benzoylthiophene (BZT) chromophore and has a $\pi, \pi^{*}$ lowest triplet excited state. In the present work, dyads $(S)$ - and $(R)$-SP- $\alpha-C h(\mathbf{1}$ and 2$)$, as well as $(S)$ SP- $\beta$-Ch (3) have been prepared from $\beta$ - or $\alpha$-Ch and SP to investigate the possible competition between photogeneration of biradicals and ${ }^{1} \mathrm{O}_{2}$, the key mechanistic steps in Ch photooxidation. Steady-state irradiation of $\mathbf{1}$ and $\mathbf{2}$ was performed in dichloromethane, under nitrogen, through Pyrex, using a $400 \mathrm{~W}$ medium pressure mercury lamp. The spectral analysis of the separated fractions revealed formation of two photoproducts $\mathbf{4}$ and $\mathbf{5}$, respectively. By contrast, under the same conditions, $\mathbf{3}$ did not give rise to any isolable Ch-derived product. These results point to an intramolecular hydrogen abstraction in $\mathbf{1}$ and $\mathbf{2}$ from the $\mathrm{C} 7$ position of $\mathrm{Ch}$ and subsequent $\mathrm{C}-\mathrm{C}$ coupling of the generated biradicals. Interestingly, $\mathbf{2}$ was significantly more photoreactive than $\mathbf{1}$ indicating a clear stereodifferentiation in the photochemical behavior. Transient absorption spectra obtained for $\mathbf{1}-\mathbf{3}$ were very similar and matched that described for the SP triplet excited state (typical bands with maxima at ca. $350 \mathrm{~nm}$ and $600 \mathrm{~nm}$ ). Direct kinetic analysis of the decay traces at $620 \mathrm{~nm}$ led to determination of triplet lifetimes that were ca. $4.1 \mu$ s for $\mathbf{1}$ and $\mathbf{2}$ and $5.8 \mu$ s for $\mathbf{3}$. From these data, the intramolecular quenching rate constants in $\mathbf{1}$ and $\mathbf{2}$ were determined as $0.78 \times 10^{5} \mathrm{~s}^{-1}$. The capability of dyads $\mathbf{1}-\mathbf{3}$ to photosensitize the production of singlet oxygen was assessed by time-resolved near infrared emission studies in dichloromethane using perinaphthenone as standard. The quantum yields $\left(\Phi_{\Delta}\right)$ were 0.52 for $\mathbf{1}$ and $\mathbf{2}$ and 0.56 for $\mathbf{3}$. In conclusion, SP- $\alpha$-Ch dyads are unique in the sense that they can be used to photogenerate both biradicals and singlet oxygen, thus being able to initiate Ch oxidation from their triplet excited states following either of the two competing mechanistic pathways.
\end{abstract}




\section{Introduction}

Among the constituents of cell membranes, cholesterol (Ch) is the most important lipidic building block. It is required for permeability, fluidity, and integrity of all animal cell membranes. However, as an unsaturated lipid, $\mathrm{Ch}$ is susceptible to oxidative degradation, which can result in potentially pathologic consequences encompassing from inflammation to cardiovascular and Alzheimer diseases [1,2]. This type of damage can be induced via free radicals or singlet oxygen $\left({ }^{1} \mathrm{O}_{2}\right)[3,4]$. The former generally involves hydrogen abstraction (HA) of an allylic hydrogen and can be achieved by photosensitizing agents in combination with UVA light. The latter involves energy transfer from the photosensitizer triplet excited state to ground state molecular oxygen $[5,6]$.

Ketoprofen (KP) is a nonsteroidal anti-inflammatory drug that contains the benzophenone (BZP, Figure 1) chromophore and displays a $n, \pi$ triplet excited state [7-9], whereas tiaprofenic acid (TPA) is a related drug that includes the 2-benzoylthiophene (BZT, Figure 1) chromophore and has a $\pi, \pi^{*}$ lowest triplet excited state $[9,10]$. Generally, the photochemical reactivity of the $n, \pi^{*}$ triplet state is higher than that of $\pi, \pi^{*}$ triplet state. It is also accepted that ketones with lowest-lying $\pi, \pi^{*}$ triplets react predominantly via thermal population of the higher energy $n, \pi^{*}$ states.<smiles>O=C(c1ccccc1)c1cccs1</smiles>

2-BZT<smiles>O=C(c1ccccc1)c1ccccc1</smiles>

BZP
Figure 1: Chemical structure of the photosensitizing chromophores benzophenone (BZP) and 2-benzoylthiophene (BZT).

In this context, we have previously shown that the electronic nature of the involved triplet excited state displays a marked in- fluence on the photobehavior of ketone-Ch dyads. Hence, $\mathrm{KP}-\alpha$-Ch dyads are suitable to generate biradicals by intramolecular HA from the C7-allyl position of Ch [11,12], whereas the TPA- $\alpha-\mathrm{Ch}$ analogs are unreactive via HA but they generate singlet oxygen efficiently [13].

Suprofen (SP) is another nonsteroidal anti-inflammatory drug, which contains a BZT chromophore. The only structural difference between SP and TPA is the site of attachment of the propionic acid side chain (Figure 2), which is the benzoyl or the thenoyl group, respectively [14,15]. Interestingly, this apparently minor modification leads to a smaller energy gap between the $T_{1}\left(\pi \pi^{*}\right)$ and the $T_{2}\left(n \pi^{*}\right)$ states in SP than in TPA (ca. 3 vs $7 \mathrm{kcal} / \mathrm{mol}$, respectively) [16]. Therefore, HA processes could be enhanced in the SP derivatives.<smiles>CC(C(=O)O)c1ccc(C(=O)c2ccccc2)s1</smiles><smiles>CC(C(=O)O)c1ccc(C(=O)c2cccs2)cc1</smiles>

Figure 2: Chemical structure of tiaprofenic acid (TPA) and suprofen (SP).

With this background, dyads (S)- and (R)-SP- $\alpha-\mathrm{Ch}$ (1 and 2), as well as $(S)$-SP- $\beta$-Ch $(\mathbf{3})$ have been prepared in the present work from $\beta$ - or $\alpha$-Ch and SP (Figure 3 ) in order to investigate the possible competition between photogeneration of biradicals and ${ }^{1} \mathrm{O}_{2}$, the key mechanistic steps in $\mathrm{Ch}$ photooxidation.

\section{Results and Discussion Preparation of dyads}

Compounds 1-3 were prepared by esterification of $\alpha$ - or $\beta$-Ch with racemic SP following standard procedures [13]. They were

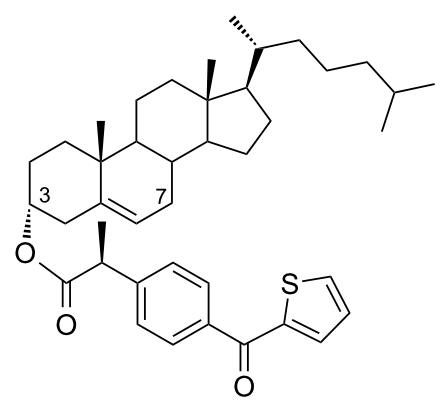

(S)-SP- $\alpha-\operatorname{Ch}(1)$

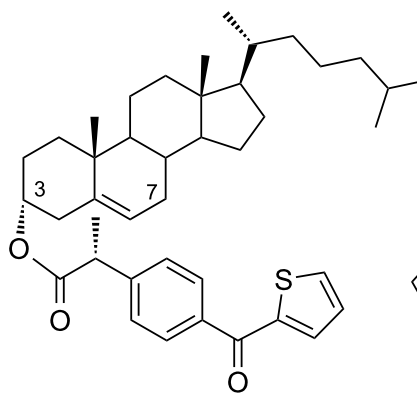

$(R)-S P-\alpha-\operatorname{Ch}(2)$<smiles>CC(C)CCC[C@H](C)C1CCC2C3CC=C4C[C@@H](OC(=O)[C@H](C)c5ccc(C(=O)c6cccs6)cc5)CC[C@]4(C)C3CC[C@@]21C</smiles>

(S)-SP- $\beta-$ Ch (3)

Figure 3: Chemical structures of dyads 1-3. 
purified and resolved into the pure diastereoisomers by fractional crystallization from hexane/ethyl acetate. Ester 1 was obtained as a pure solid, while its diastereoisomer $\mathbf{2}$ remained as a viscous oil after elimination of the solvent from the filtered solution. In order to make an unambiguous stereochemical assignment, authentic samples of $\mathbf{1}$ and $\mathbf{2}$ were prepared by direct esterification of $(R)$ - and $(S)$-SP with $\alpha$-Ch [17].

\section{Steady-state photolysis}

In order to investigate photoproducts formation, steady-state irradiation of dichloromethane solutions (ca. $10^{-3} \mathrm{M}$ ) of 1-3 was performed under nitrogen, using a Pyrex filter and a $400 \mathrm{~W}$ medium pressure mercury lamp. The reaction progress was followed by TLC and NMR. The resulting photomixtures were submitted to silica gel column chromatography, using hexane/ ethyl acetate $(95: 5 \mathrm{v} / \mathrm{v})$ as eluent. The spectral analysis of the separated fractions revealed the formation of two new diastereomeric photoproducts $\mathbf{4}$ and $\mathbf{5}$ from dyads $\mathbf{1}$ and $\mathbf{2}$, respectively (Scheme 1). By contrast, (S)-SP- $\beta$-Ch (3) did not give rise to any isolable Ch-derived product; this is in agreement with conformational restrictions, which do not allow an effective approach between the two active moieties. The nature of the photoproducts formed from $\mathbf{1}$ and $\mathbf{2}$ point to an intramolecular $\mathrm{HA}$ from the $\mathrm{C} 7$ position of $\mathrm{Ch}$ and subsequent $\mathrm{C}-\mathrm{C}$ coupling of the generated biradicals.

The structures of compounds $\mathbf{4}$ and $\mathbf{5}$ were unambiguously assigned on the basis of their NMR spectroscopic data $\left({ }^{1} \mathrm{H},{ }^{13} \mathrm{C}\right.$,
HSQC and NOEDIFF) and mass spectrometry analysis, including high-resolution measurements. Because of the rigidity of the steroidal skeleton, NOE experiments were necessary to assign the stereochemistry of the new chiral centers generated upon photocyclization. In both photoproducts, the most relevant interaction was found between the allylic proton at $\mathrm{C} 7$ and the protons of the thiophene ring (Figure 4). More details are provided in the Supporting Information File 1.

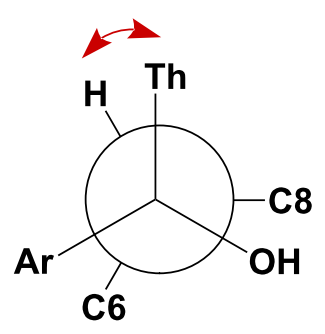

Figure 4: Diagnostic NOE interactions in compounds 4 and 5.

Having established the nature of the occurring photochemical reactions, it appeared interesting to explore the possible stereodifferentiation in the HA process. Thus, irradiation of 1-3 was performed with monochromatic light at $266 \mathrm{~nm}$ in $\mathrm{CH}_{2} \mathrm{Cl}_{2}$ (ca. $10^{-5} \mathrm{M}$ solutions), under nitrogen. The changes were monitored by UV-spectrophotometry, following the decrease in the maximum absorption at $290 \mathrm{~nm}$ (inset of Figure 5), which is consistent with reduction of the BZT chromophore.

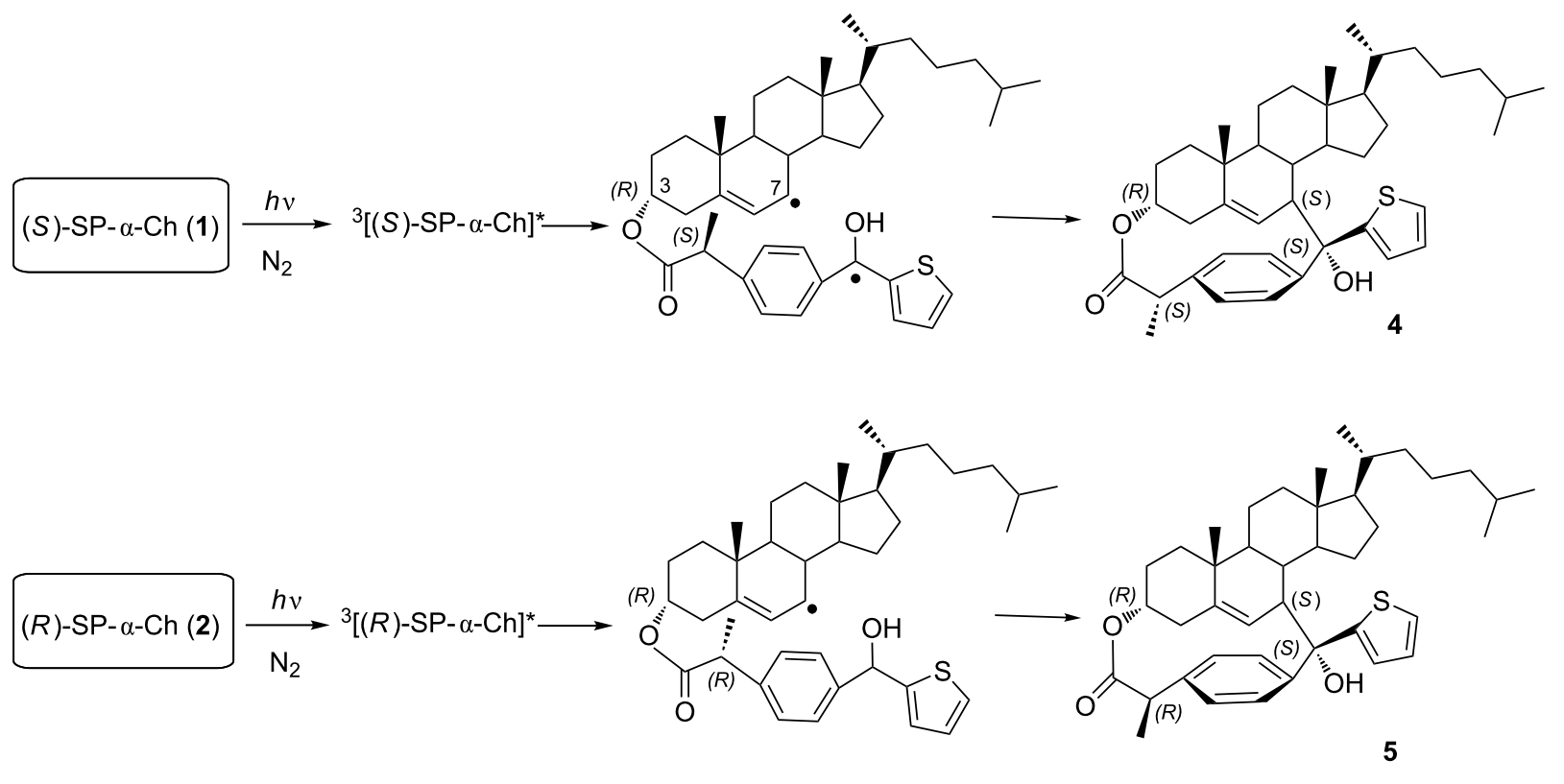




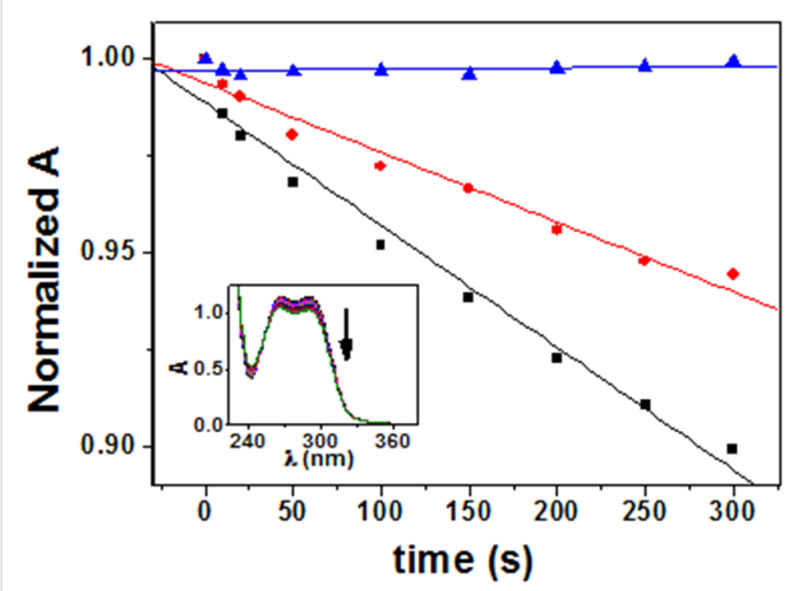

Figure 5: Decrease of the absorbance at $290 \mathrm{~nm}$ upon irradiation in $\mathrm{CH}_{2} \mathrm{Cl}_{2}$ under $\mathrm{N}_{2}$ for $\mathbf{1}$ (red circles), 2 (black squares) and $\mathbf{3}$ (blue triangles) as a function of the irradiation time. Inset: changes in the absorption spectrum of a deaerated dichloromethane solution of 1 after increasing irradiation times with monochromatic light at $\lambda=266 \mathrm{~nm}$.

Dyads $\mathbf{1}$ and $\mathbf{2}$ were efficiently photolyzed under anaerobic conditions, whereas $\mathbf{3}$ was markedly unreactive. Interestingly, $\mathbf{2}$ was significantly more photoreactive than $\mathbf{1}$ indicating a clear stereodifferentiation in the photochemical behavior.

\section{Laser flash photolysis (LFP)}

The studies were carried out in dichloromethane under anaerobic atmosphere at $\lambda_{\text {exc }}=355 \mathrm{~nm}$. Transient absorption spectra acquired for $\mathbf{1}-\mathbf{3}$ (Figure 6 ) were all very similar to that previously reported for the triplet excited state of SP, with maxima at ca. $350 \mathrm{~nm}$ (major) and $600 \mathrm{~nm}$ (minor) [18].

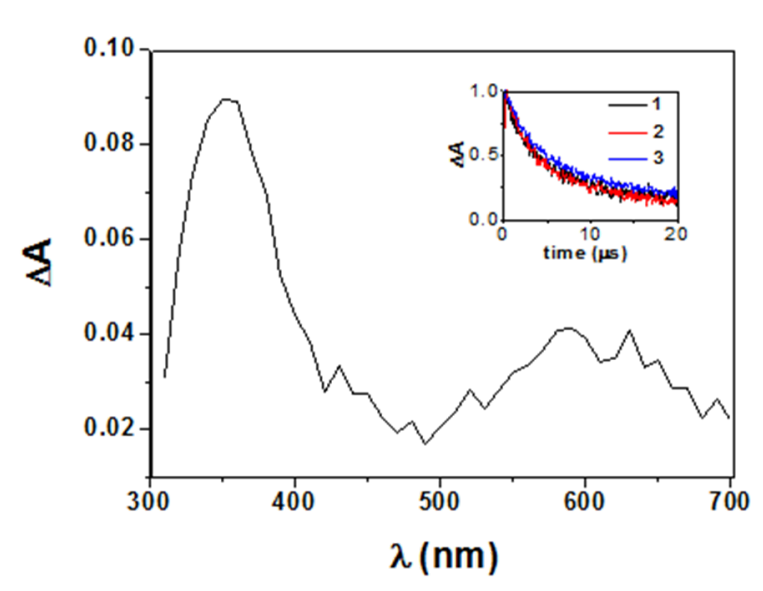

Figure 6: Transient absorption spectra for dyad 1 in $\mathrm{CH}_{2} \mathrm{Cl}_{2} 1 \mu$ s after laser pulse $\left(\lambda_{\mathrm{exc}}=355 \mathrm{~nm}\right)$. Inset: Normalized decays of the triplets generated from dyads $1-3$ monitored at $620 \mathrm{~nm}$.

An overall mechanistic picture is shown in Scheme 2 and a summary of photophysical parameters is provided in Table 1 , together with reference values from the literature [19-21]. The direct kinetic analysis of the decay traces at $620 \mathrm{~nm}$ (Figure 6 inset) led to determination of triplet lifetimes $\left(\tau_{\mathrm{T}}\right)$ that were ca.

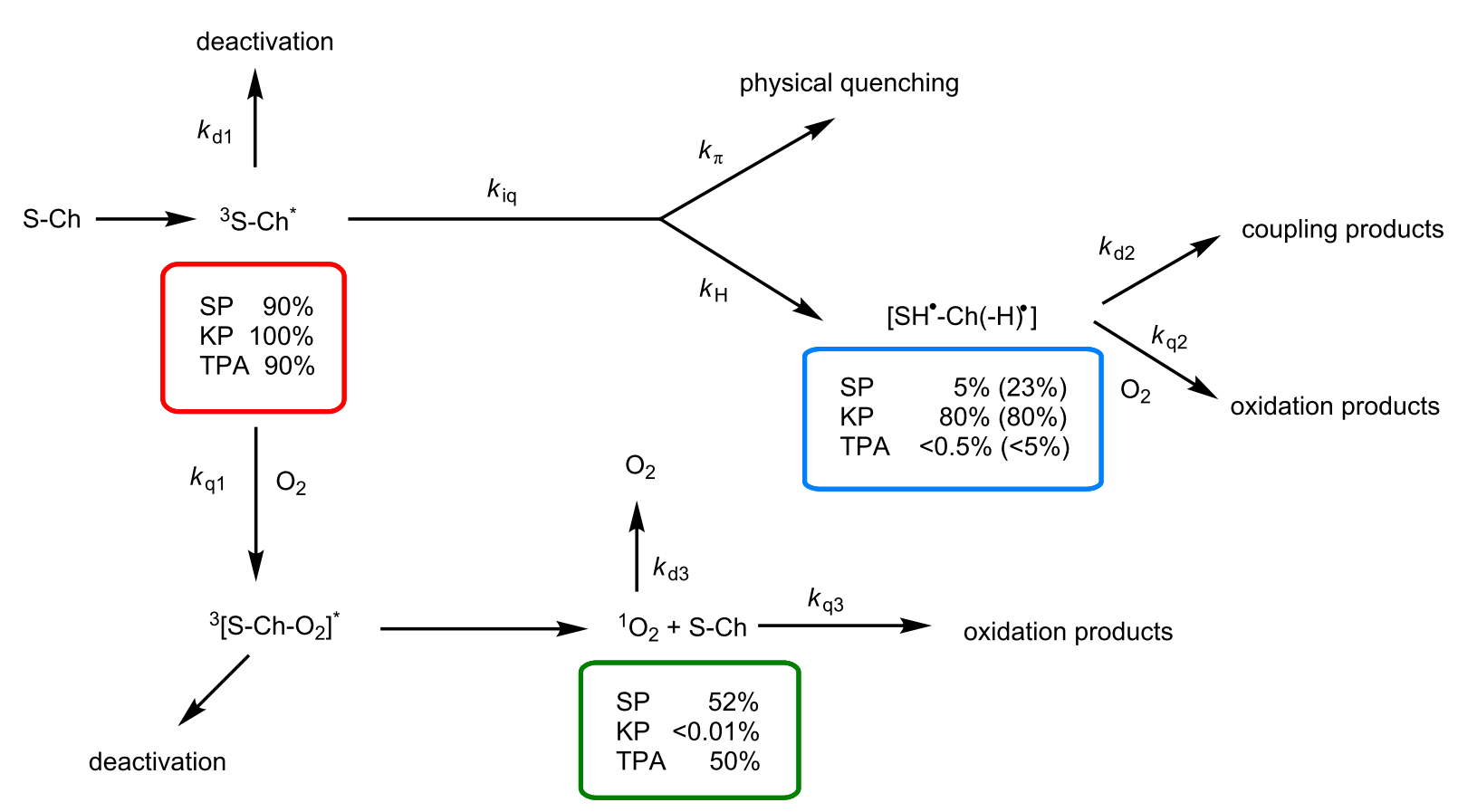

Scheme 2: Photoreaction pathways generating biradical and singlet oxygen species of a sensitizer (S), like SP, KP or TPA, covalently linked to Ch. The obtained percentages under anaerobic conditions are given in parenthesis. 
$4.1 \mu$ s for $\mathbf{1}$ and $\mathbf{2}$ and $5.8 \mu$ s for $\mathbf{3}$. From these data, the intramolecular quenching rate constants were determined as $k_{\mathrm{iq}}=1 / \tau_{\mathrm{T}(\mathbf{1} \text { or } 2)}-1 / \tau_{\mathrm{T}(\mathbf{3})}$, and the value obtained for $\mathbf{1}$ and $\mathbf{2}$ was $0.78 \times 10^{5} \mathrm{~s}^{-1}$.

Table 1: Photophysical parameters of dyads in $\mathrm{CH}_{2} \mathrm{Cl}_{2}$.

\begin{tabular}{lll} 
Parameters & $\begin{array}{l}(\mathrm{S}) \text { - or }(R)-\mathrm{SP}-\mathrm{\alpha}-\mathrm{Ch} \\
(\mathbf{1}, \mathbf{2})\end{array}$ & $\mathrm{KP}-\mathrm{\alpha}-\mathrm{Ch}^{\mathrm{a}}$ \\
\hline$\Phi_{\text {isc }}$ & $0.9^{\mathrm{b}}$ & $1.0^{\mathrm{c}}$ \\
$k_{\mathrm{d} 1}\left[\mathrm{~s}^{-1}\right]$ & $1.7 \times 10^{5 \mathrm{~d}}$ & $5.9 \times 10^{5}$ \\
$k_{\mathrm{iq}}\left[\mathrm{s}^{-1}\right]$ & $7.8 \times 10^{4 \mathrm{e}}$ & $1.0 \times 10^{8}$ \\
$k_{\mathrm{H}}\left[\mathrm{s}^{-1}\right]$ & $6.2 \times 10^{4 \mathrm{f}}$ & $8.0 \times 10^{7}$ \\
$K_{\mathrm{m}}\left[\mathrm{s}^{-1}\right]$ & $1.6 \times 10^{4 \mathrm{f}}$ & $2.0 \times 10^{7}$ \\
$k_{\mathrm{q} 1}\left[\mathrm{M}^{-1} \mathrm{~s}^{-1}\right]$ & $0.4 \times 10^{9}$ & $0.6 \times 10^{9}$ \\
$\Phi_{\Delta}$ & 0.52 & $<0.01$ \\
$k_{\mathrm{d} 2}\left[\mathrm{~s}^{-1}\right]$ & $\mathrm{NDg}$ & $5.0 \times 10^{6}$ \\
$k_{\mathrm{q} 2}\left[\mathrm{M}^{-1} \mathrm{~s}^{-1}\right]$ & $\mathrm{NDg}$ & $3.6 \times 10^{9}$ \\
$k_{\mathrm{d} 3}\left[\mathrm{~s}^{-1}\right]$ & $1.4 \times 10^{\mathrm{h}}$ & $1.3 \times 10^{4}$ \\
$k_{\mathrm{q} 3}\left[\mathrm{M}^{-1} \mathrm{~s}^{-1}\right]$ & $5.7 \times 10^{4 \mathrm{i}}$ & $5.7 \times 10^{4 \mathrm{i}}$ \\
$\mathrm{T}_{\mathrm{T}}[\mu \mathrm{s}]$ & 4.10 & $<0.01$ \\
\hline
\end{tabular}

aValues taken from ref. [13]; bvalue taken from ref. [15]; ' $v a l u e$ taken from ref. [19]; ${ }^{\left.\mathrm{d}_{\mathrm{d} 1}=1 / \mathrm{T}_{\mathrm{T}(3)}\right)}$; the intramolecular quenching rate constants were estimated as $k_{\mathrm{iq}}=1 / \mathrm{T}_{\mathrm{T}(1}$ or 2$)-1 / \mathrm{T}_{\mathrm{T}(3)}$; f the rate constants for $\mathrm{HA}\left(k_{\mathrm{H}}\right)$ and physical quenching by the $\pi$ system $\left(k_{\pi}\right)$ were obtained by assuming that their ratio is similar to that determined in KP- $\alpha-$

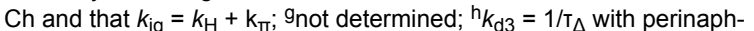
thenone as photosensitizer (value taken from ref. [20]); ivalue taken from ref. [21].

Unfortunately, in the nanosecond timescale it was not possible to detect the biradical species. Indeed, the coupling rate constant $\left(k_{\mathrm{d} 2}\right)$ should be similar to that of KP- $\alpha$-Ch and therefore much higher than the hydrogen abstraction rate constant $\left(k_{\mathrm{H}}\right)$, which is by definition lower than $k_{\text {iq }}$. Consequently, biradicals are not expected to accumulate since their consumption is much faster than their formation.

It is interesting to note that the reverse is true that for the KP- $\alpha$ $\mathrm{Ch}$ analogs, where $k_{\mathrm{d} 2}$ is lower than $k_{\mathrm{H}}$ (Table 1). Therefore, biradical accumulation is indeed observed in this case, because the coupling products are generated much more slowly.

\section{Singlet oxygen generation}

To assess the capability of dyads $\mathbf{1}-\mathbf{3}$ to photosensitize the production of excited singlet molecular oxygen $\left({ }^{1} \mathrm{O}_{2}\right.$ or $\left.{ }^{1} \Delta_{\mathrm{g}}\right)$, timeresolved near infrared emission studies were carried out in dichloromethane using perinaphthenone (PN) as standard. The formation of this reactive oxygen species was detected by its luminescence at $1270 \mathrm{~nm}$, using a germanium diode as detector. The singlet oxygen lifetime (Figure 7A) was found to be ca. $70 \mu \mathrm{s}$ in all cases (in agreement with the ${ }^{1} \mathrm{O}_{2}$ lifetime reported in the literature [20] for the same solvent). The photosensitized singlet oxygen production was established with a quantum yield $\left(\Phi_{\Delta}\right)$ of 0.52 for $\mathbf{1}$ and $\mathbf{2}$ and 0.56 for $\mathbf{3}$ (Table 1 and Figure 7B).

\section{Biradical vs singlet oxygen}

Although it was not possible to detect the biradical species by means of LFP in SP- $\alpha$-Ch systems, its generation (5\%) has been chemically proven by obtaining the coupling products $\mathbf{4}$ and $\mathbf{5}$. Moreover, the triplet excited states of $\mathbf{1}$ and $\mathbf{2}$ were quenched by $\mathrm{O}_{2}$ to generate ${ }^{1} \mathrm{O}_{2}$ efficiently (52\%). Interestingly, the TPA analogs (also with $\pi, \pi^{*}$ character) are unreactive via intramolecular HA $(<0.5 \%)$, while they produce ${ }^{1} \mathrm{O}_{2}$ with a $\Phi_{\Delta}=0.5$. By

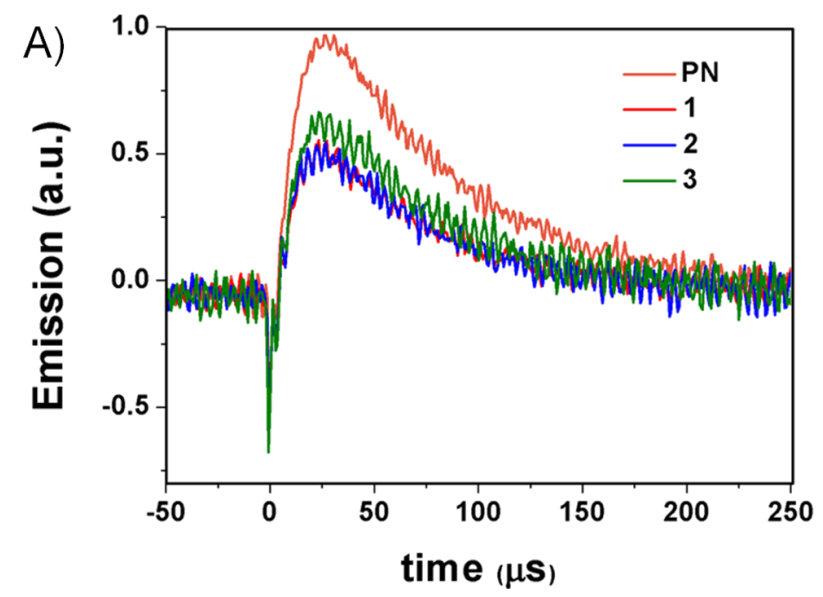

B)

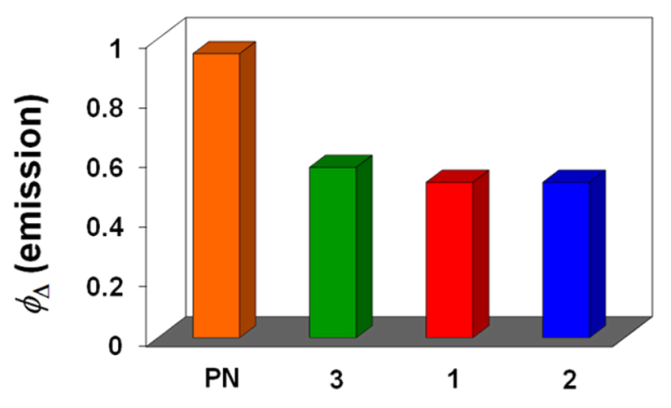

Figure 7: Time-resolved experiments at $1270 \mathrm{~nm}$ upon excitation at $308 \mathrm{~nm}$ of aerated $\mathrm{CH}_{2} \mathrm{Cl}_{2}$ solutions of 1-3, using perinaphthenone as standard for comparison. A) Luminiscence decays of ${ }^{1} \mathrm{O}_{2}$. B) Formation of ${ }^{1} \mathrm{O}_{2}$. 
contrast, for KP derivatives $\left({ }^{3} n, \pi^{*}\right)$, efficient photogeneration of 7-allyl-Ch biradicals $(80 \%)$ is observed, and ${ }^{1} \mathrm{O}_{2}$ production is negligible $(<0.01)$.

In conclusion, SP- $\alpha$-Ch dyads are unique in the sense that they can be used to photogenerate both biradicals and singlet oxygen, thus being able to initiate $\mathrm{Ch}$ oxidation from their triplet excited states following either of the two competing mechanistic pathways.

\section{Experimental General}

Suprofen and $\beta$-cholesterol were commercially available. Solvents and other reagents were used as received from the supplier without additional purification. ${ }^{1} \mathrm{H} \mathrm{NMR}$ and ${ }^{13} \mathrm{C}$ NMR spectra were recorded in $\mathrm{CDCl}_{3}$ as solvent on a Bruker AC-300 at 300 and $75 \mathrm{MHz}$, respectively, and the NMR chemical shifts are reported in ppm downfield from an internal solvent peak. Ultraviolet absorption spectra were recorded on a Varian Cary 300 scan UV-vis spectrophotometer. All reactions were monitored by analytical TLC with silica gel $60 \mathrm{~F}_{254}$ revealed with ammonium molybdate reagent. The residues were purified through silica gel $60(0.063-0.2 \mathrm{~mm})$. Exact mass was obtained by Waters ACQUITYTм XevoQToF spectrometer.

\section{Laser flash photolysis (LFP) measurements}

As described in [17], a pulsed Nd:YAG laser was used for the excitation at $355 \mathrm{~nm}$. The single pulses were of $\sim 10$ ns duration, and the energy was from 10 to $1 \mathrm{~mJ} /$ pulse. The LFP system consisted of the pulsed laser, the Xe lamp, a monochromator and a photomultiplier made up of a tube, housing and power supply. The output signal from the oscilloscope was transferred to a personal computer. All experiments were performed at room temperature. The samples were dissolved in dichloromethane to have an absorbance of ca. 0.30 at $355 \mathrm{~nm}$, and solutions were deareated by bubbling nitrogen.

\section{Steady-state photolysis of dyads $\mathbf{1}$ and $\mathbf{2}$}

Solutions of 1,2 or 3 (ca. $10^{-4} \mathrm{M}$ concentration) were irradiated, under anaerobic conditions, with monochromatic light at $266 \mathrm{~nm}$ using the Xe lamp of a Photon, Tecnology spectrofluorometer equipped with monochromator. The changes were monitored by UV-vis spectrophotometry following the decrease in the absorption at $290 \mathrm{~nm}$.

To preparative scale, deaerated dichlorometane $(20 \mathrm{~mL})$ solutions of $(S)$ - or $(R)$ - $\alpha$-Ch dyads 1 and $2(150 \mathrm{mg}, 0.24 \mathrm{mmol})$ were irradiated for $8 \mathrm{~h}$ through Pyrex with a $400 \mathrm{~W}$ medium pressure mercury lamp. After this time the reaction mixtures were concentrated under reduced pressure, and the photomixtures were submitted to silica gel column chromatography, using hexane/ethyl acetate (eluent: 98:2), which afforded the pure photoproducts $\mathbf{4}$ and $\mathbf{5}$.

\section{Data for compounds $\mathbf{4}$ and $\mathbf{5}$ Photoproduct 4 (51\%)}

${ }^{1} \mathrm{H} \mathrm{NMR}\left(\mathrm{CDCl}_{3}, 300 \mathrm{MHz}\right) \delta 0.53(\mathrm{~s}, 3 \mathrm{H}), 0.79(\mathrm{~d}, J=6.6 \mathrm{~Hz}$, $3 \mathrm{H}), 0.80(\mathrm{~d}, J=6.6 \mathrm{~Hz}, 3 \mathrm{H}), 0.82(\mathrm{~s}, 3 \mathrm{H}), 0.87(\mathrm{~d}, J=6.6 \mathrm{~Hz}$, $3 \mathrm{H}), 1.57$ (d, $J=7.2 \mathrm{~Hz}, 3 \mathrm{H}), 0.90-1.98$ (complex signal, $24 \mathrm{H}$ ), $2.18(\mathrm{~m}, 1 \mathrm{H}), 2.49(\mathrm{~m}, 1 \mathrm{H}), 2.69(\mathrm{~s}, 1 \mathrm{H}), 3.09(\mathrm{~m}, 1 \mathrm{H}), 3.62(\mathrm{q}$, $J=7.2 \mathrm{~Hz}, 1 \mathrm{H}), 4.59(\mathrm{~m}, 1 \mathrm{H}), 4.70(\mathrm{~m}, 1 \mathrm{H}), 6.44(\mathrm{dd}, J=8.1$ $\mathrm{Hz}, 2.0 \mathrm{~Hz}, 1 \mathrm{H}), 6.83(\mathrm{dd}, J=8.1 \mathrm{~Hz}, 2.0 \mathrm{~Hz}, 1 \mathrm{H}), 6.99(\mathrm{dd}, J=$ $5.1 \mathrm{~Hz}, 3.6 \mathrm{~Hz}, 1 \mathrm{H}), 7.11(\mathrm{dd}, J=3.6 \mathrm{~Hz}, 1.2 \mathrm{~Hz}, 1 \mathrm{H}), 7.25$ (dd, $J=5.1 \mathrm{~Hz}, 1.2 \mathrm{~Hz}, 1 \mathrm{H}), 7.28(\mathrm{~m}, 1 \mathrm{H}), 7.74(\mathrm{dd}, J=8.1 \mathrm{~Hz}, 2.0$ $\mathrm{Hz}, 1 \mathrm{H}) ;{ }^{13} \mathrm{C} \mathrm{NMR}\left(\mathrm{CDCl}_{3}, 75 \mathrm{MHz}\right) \delta 10.2,13.6,18.8,18.9$, $20.5,22.6,22.9,23.8,25.5,26.7,28.1,33.1,35.8,36.1,36.2$, $38.1,39.2,39.6,40.2,41.1,42.9,46.6,46.7,50.2,56.1,70.2$, 83.9, 124.7, 124.9, 125.0, 125.9, 126.1, 126.7, 128.0, 135.7, 139.7, 146.8, 156.2, 173.4; HRMS-EI $(\mathrm{m} / \mathrm{z}):[\mathrm{M}-\mathrm{H}]^{+}$calcd for $\mathrm{C}_{41} \mathrm{H}_{55} \mathrm{O}_{3} \mathrm{~S}, 627.3866$; found, 627.3865

\section{Photoproduct 5 (53\%)}

${ }^{1} \mathrm{H} \mathrm{NMR}\left(\mathrm{CDCl}_{3}, 300 \mathrm{MHz}\right) \delta 0.53(\mathrm{~s}, 3 \mathrm{H}), 0.79(\mathrm{~d}, J=6.6 \mathrm{~Hz}$, $3 \mathrm{H}), 0.80(\mathrm{~d}, J=6.6 \mathrm{~Hz}, 3 \mathrm{H}), 0.82(\mathrm{~s}, 3 \mathrm{H}), 0.87(\mathrm{~d}, J=6.6 \mathrm{~Hz}$, $3 \mathrm{H}), 1.49$ (d, $J=7.2 \mathrm{~Hz}, 3 \mathrm{H}), 0.90-1.97$ (complex signal, $24 \mathrm{H}$ ), $2.14(\mathrm{~m}, 1 \mathrm{H}), 2.46(\mathrm{~m}, 1 \mathrm{H}), 2.70(\mathrm{~s}, 1 \mathrm{H}), 3.06(\mathrm{~m}, 1 \mathrm{H}), 3.57(\mathrm{q}$, $J=7.2 \mathrm{~Hz}, 1 \mathrm{H}), 4.55(\mathrm{dd}, J=5.4 \mathrm{~Hz}, 1.5 \mathrm{~Hz}, 1 \mathrm{H}), 4.68(\mathrm{~m}$, $1 \mathrm{H}), 6.48(\mathrm{dd}, J=8.1 \mathrm{~Hz}, 2.0 \mathrm{~Hz}, 1 \mathrm{H}), 6.92$ (dd, $J=8.1 \mathrm{~Hz}, 2.0$ $\mathrm{Hz}, 1 \mathrm{H}), 6.98(\mathrm{dd}, J=5.1 \mathrm{~Hz}, 3.6 \mathrm{~Hz}, 1 \mathrm{H}), 7.09(\mathrm{dd}, J=3.6 \mathrm{~Hz}$, $1.2 \mathrm{~Hz}, 1 \mathrm{H}), 7.19$ (dd, $J=8.1 \mathrm{~Hz}, 2.0 \mathrm{~Hz}, 1 \mathrm{H}), 7.24$ (dd, $J=5.1$ $\mathrm{Hz}, 1.2 \mathrm{~Hz}, 1 \mathrm{H}), 7.66(\mathrm{dd}, J=8.1 \mathrm{~Hz}, 2.0 \mathrm{~Hz}, 1 \mathrm{H}) ;{ }^{13} \mathrm{C} \mathrm{NMR}$ $\left(\mathrm{CDCl}_{3}, 75 \mathrm{MHz}\right) \delta 10.2,13.1,18.8,19.1,20.5,22.6,22.9$, 23.7, 25.9, 26.6, 28.1, 32.7, 35.3, 35.8, 36.2, 38.0, 39.2, 39.6, 40.1, 41.2, 42.9, 45.8, 46.4, 50.2, 56.1, 69.7, 84.0, 123.1, 124.7, 124.9, 125.7, 125.9, 126.7, 128.5, 130.8, 134.9, 140.1, 147.0, 156.0, 172.9; HRMS-EI $(m / z)$ : $[\mathrm{M}-\mathrm{H}]^{+}$calcd for $\mathrm{C}_{41} \mathrm{H}_{55} \mathrm{O}_{3} \mathrm{~S}$, 627.3866; found, 627.3846 .

\section{Singlet oxygen measurements}

As described in [13], the luminescence $(1270 \mathrm{~nm})$ from singlet oxygen was detected by means of an Oriel 71614 germanium photodiode $\left(5 \mathrm{~mm}^{2}\right)$ coupled to the laser photolysis cell in rightangle geometry. An excimer laser (LEXTRA50 Lambda Physik) was used for the excitation at $308 \mathrm{~nm}$ (laser excitation at 5 low-pulse energies for each molecule). A $5 \mathrm{~mm}$ thick $(5 \mathrm{~cm}$ in diameter) $1050 \mathrm{~nm}$ cut-off silicon filter and a $1270 \mathrm{~nm}$ interference filter were placed between the diode and the cell. The photodiode output current was amplified and fed into a TDS640A Tektronix oscilloscope via a Co-linear $150 \mathrm{MHz}, 20 \mathrm{~dB}$ amplifier. The output signal from the oscilloscope was transferred to a personal computer for study. Thus, the singlet oxygen quantum yield $\left(\Phi_{\Delta}\right)$ of the dyads was determined in 
dichloromethane solutions using the same absorbance value $(0.30)$ at $308 \mathrm{~nm}$ for each compound. A singlet oxygen quantum yield $\left(\Phi_{\Delta}\right)$ of 0.95 for perinaphthenone in dichloromethane was used as standard [22].

\section{Supporting Information}

\section{Supporting Information File 1}

Copies of ${ }^{1} \mathrm{H},{ }^{13} \mathrm{C}$, DEPT, HSQC and NOEDIFF spectra for photoproducts $\mathbf{4}$ and $\mathbf{5}$.

[http://www.beilstein-journals.org/bjoc/content/

supplementary/1860-5397-12-115-S1.pdf]

\section{Acknowledgements}

Financial support from the Generalitat Valenciana (Prometeo Program), the Spanish Government (CTQ2014-54729-C2-2-P and FPU fellowship for F.P.) and the Carlos III Institute of Health (Grant RIRAAF, RETICS program and Miguel Servet Contract CP11/00154 for I. A.) is gratefully acknowledged.

\section{References}

1. Schroepfer, G. J., Jr. Physiol. Rev. 2000, 80, 361-554.

2. Lercker, G.; Rodriguez-Estrada, T. In Cholesterol and Phytosterol Oxidation Products; Guardiola, F.; Dutta, P. C.; Codony, R.; Savage, G. P., Eds.; AOCS Press: Champaign, 2002; pp 1-25.

3. Iuliano, L. Chem. Phys. Lipids 2011, 164, 457-468. doi:10.1016/j.chemphyslip.2011.06.006

4. Foote, C. S. Free Radicals in Biology; Academic Press: New York, 1976; Vol. 2, pp 85-134.

5. Girotti, A. W. Antioxid. Redox Signaling 2004, 6, 301-310. doi:10.1089/152308604322899369

6. Girotti, A. W.; Bachowski, G. J.; Jordan, J. E. Lipids 1987, 22, 401-408. doi:10.1007/BF02537268

7. Encinas, M. V.; Scaiano, J. C. J. Am. Chem. Soc. 1981, 103, 6393-6397. doi:10.1021/ja00411a021

8. Marković, D. Z.; Durand, T.; Patterson, L. K. Photochem. Photobiol. 1990, 51, 389-394. doi:10.1111/j.1751-1097.1990.tb01729.x

9. Boscá, F.; Miranda, M. A. J. Photochem. Photobiol., B: Biol. 1998, 43, 1-26. doi:10.1016/S1011-1344(98)00062-1

10. Boscá, F.; Miranda, M. A.; Morera, I. M.; Samadi, A. J. Photochem. Photobiol., B 2000, 58, 1-5. doi:10.1016/S1011-1344(00)00102-0

11. Andreu, I.; Boscá, F.; Sanchez, L.; Morera, I. M.; Camps, P.; Miranda, M. A. Org. Lett. 2006, 8, 4597-4600. doi:10.1021/ol061854c

12. Neshchadin, D.; Palumbo, F.; Sinicropi, M. S.; Andreu, I.; Gescheidt, G.; Miranda, M. A. Chem. Sci. 2013, 4, 1608-1614. doi:10.1039/c3sc22109a

13. Andreu, I.; Morera, I. M.; Boscá, F.; Sanchez, L.; Camps, P.; Miranda, M. A. Org. Biomol. Chem. 2008, 6, 860-867. doi:10.1039/b718068c

14. Castell, J. V.; Gomez-Lechon, M. J.; Grassa, C.; Martinez, L. A.; Miranda, M. A.; Tarrega, P. Photochem. Photobiol. 1994, 59, 35-39. doi:10.1111/j.1751-1097.1994.tb04998.x
15. Encinas, S.; Miranda, M. A.; Marconi, G.; Monti, S. Photochem. Photobiol. 1998, 68, 633-639. doi:10.1111/j.1751-1097.1998.tb02522.x

16. Encinas, S.; Miranda, M. A.; Marconi, G.; Monti, S. Photochem. Photobiol. 1998, 67, 420-425. doi:10.1111/j.1751-1097.1998.tb05221.x

17. Andreu, I.; Morera, I.; Palumbo, F.; Sastre, G.; Bosca, F.; Miranda, M. A. Chem. Sci. 2015, 6, 4035-4041. doi:10.1039/C5SC00823A

18. Pérez-Prieto, J.; Boscá, F.; Galian, R. E.; Lahoz, A.; Domingo, L. R.; Miranda, M. A. J. Org. Chem. 2003, 68, 5104-5113. doi:10.1021/jo034225e

19. Aloïse, S.; Ruckebusch, C.; Blanchet, L.; Réhault, J.; Buntinx, G.; Huvenne, J.-P. J. Phys. Chem. A 2008, 17, 224-231. doi:10.1021/jp075829f

20. Rodgers, M. A. J. J. Am. Chem. Soc. 1983, 105, 6201-6205. doi:10.1021/ja00358a001

21. Vever-Bizet, C.; Dellinger, M.; Brault, D.; Rougee, M.; Bensasson, R. V. Photochem. Photobiol. 1989, 50, 321-325. doi:10.1111/j.1751-1097.1989.tb04165.x

22. Nonell, S.; González, M.; Trull, F. R. Afinidad 1993, 50, 445-450.

\section{License and Terms}

This is an Open Access article under the terms of the Creative Commons Attribution License (http://creativecommons.org/licenses/by/2.0), which permits unrestricted use, distribution, and reproduction in any medium, provided the original work is properly cited.

The license is subject to the Beilstein Journal of Organic Chemistry terms and conditions:

(http://www.beilstein-journals.org/bjoc)

The definitive version of this article is the electronic one which can be found at: doi:10.3762/bjoc. 12.115 